\title{
Metabolic Reprogramming in COVID-19
}

\author{
Tao Shen ${ }^{1,2}$ and Tingting Wang ${ }^{1,2, *}$
}

1 The State Key Laboratory of Pharmaceutical Biotechnology, Division of Immunology, Medical School, Nanjing University, Nanjing 210093, China; 181230029@smail.nju.edu.cn

2 Jiangsu Key Laboratory of Molecular Medicine, Division of Immunology, Medical School, Nanjing University, Nanjing 210093, China

* Correspondence: wangtt@nju.edu.cn

\section{check for}

updates

Citation: Shen, T.; Wang, T. Metabolic Reprogramming in COVID-19. Int. J. Mol. Sci. 2021, 22, 11475. https://doi.org/10.3390/ ijms222111475

Academic Editor: Evgenii Gusev

Received: 26 September 2021

Accepted: 21 October 2021

Published: 25 October 2021

Publisher's Note: MDPI stays neutral with regard to jurisdictional claims in published maps and institutional affiliations.

Copyright: (c) 2021 by the authors. Licensee MDPI, Basel, Switzerland. This article is an open access article distributed under the terms and conditions of the Creative Commons Attribution (CC BY) license (https:// creativecommons.org/licenses/by/ $4.0 /)$.

\begin{abstract}
Plenty of research has revealed virus induced alternations in metabolic pathways, which is known as metabolic reprogramming. Studies focusing on COVID-19 have uncovered significant changes in metabolism, resulting in the perspective that COVID-19 is a metabolic disease. Reprogramming of amino acid, glucose, cholesterol and fatty acid is distinctive characteristic of COVID-19 infection. These metabolic changes in COVID-19 have a critical role not only in producing energy and virus constituent elements, but also in regulating immune response, offering new insights into COVID-19 pathophysiology. Remarkably, metabolic reprogramming provides great opportunities for developing novel biomarkers and therapeutic agents for COVID-19 infection. Such novel agents are expected to be effective adjuvant therapies. In this review, we integrate present studies about major metabolic reprogramming in COVID-19, as well as the possibility of targeting reprogrammed metabolism to combat virus infection.
\end{abstract}

Keywords: COVID-19; metabolic changes; tryptophan; arginine; glucose; cholesterol; fatty acids

\section{Introduction}

Viruses are morbific pathogens which rely on host cell machinery to achieve their entry, replication, maturation and dissemination [1]. Therefore, it is understandable that viruses have evolved to induce metabolic reprogramming in host cells to create a hospitable environment for their survival [2]. Different virus species tend to trigger different metabolic alternations in order to satisfy their unique requirement for successful spread [3]. While the complex mechanism of host-virus interaction remains to be revealed, it is evident that metabolic reprogramming is closely associated with outcomes of viral infections, emphasizing their potential role in developing antiviral agents [4].

The COVID-19 pandemic, whose causative agent is severe acute respiratory syndrome coronavirus 2 (SARS-CoV-2), places an extraordinary burden on public health [5]. Acute respiratory distress syndrome (ARDS), a characteristic of many critical COVID-19 cases, is likely to arise from immune dysfunction which is featured with cytokine storm [6]. Metabolic diseases such as diabetes and obesity have long been established to cause immune dysfunction, with impairment to both the innate and adaptive immune system [7]. As a result, it is not difficult to understand the high prevalence of diabetes, obesity, and risk factors for cardiovascular disease in critical COVID-19 cases [8]. Given the confirmed association between metabolic diseases and the severity of COVID-19 infection, as well as the close relation between immune response and metabolism alternations, metabolic reprogramming in COVID-19 pathophysiology has attracted considerable interest [8,9]. In this review, we gather the present understanding about metabolic reprogramming in COVID-19 and discuss how the exploitation of a reprogrammed metabolism offers novel therapeutic paradigms. 


\section{Metabolism Reprogramming in COVID-19 Infection}

\subsection{Amino Acid Metabolism}

As amino acid metabolism plays a significant part in the regulation of immune responses and the assembly of progeny virus [10-12], alternations of amino acid metabolism over the course of SARS-CoV-2 infection has become one of the focuses in COVID-19 research. In this article, we will review the changes in the tryptophan, arginine and glutamine metabolisms of COVID-19 patients, which have been subject to more extensive research.

\subsubsection{Tryptophan Pathways}

Tryptophan (Trp), an essential amino acid, has four known downriver metabolism pathways: the kynurenine, decarboxylation and transamination and serotonin pathways [13]. An overwhelming percentage of tryptophan is catabolized along the kynurenine pathway and generates a variety of metabolites with recognized biological roles in regulating immune responses $[14,15]$. In the kynurenine pathway, the generation of $\mathrm{N}$ formylkynurenine derived from Trp is the rate determining step via the enzyme activity of indoleamine-2,3-dioxygenase 1 (IDO1), IDO2 and tryptophan-2,3-dioxygenase (TDO) [16]. Consumption of Trp weakens the immune reactions by enhancing regulatory $\mathrm{T}$ cells (Treg) activity, and inhibiting T effector cells $[17,18]$.

In COVID-19 infection, kynurenine-to-tryptophan ratio is increased, suggesting the activation of the kynurenine pathway [19]. The increase of kynurenine and several downstream products, as well as the decrease in tryptophan, serotonin, and indolepyruvate levels, which validates the alternation of the kynurenine pathway, has also been revealed by several metabolomic analyses [20-25]. Notably, the changes in the kynurenine pathway correlate with disease severity $[19,21,25]$. This can be explained as follows. Activation of the kynurenine pathway may be a result of excessive inflammatory responses in COVID-19 patients, given interferon (IFN) $\gamma$ and other inflammatory factors can upregulate IDO [26,27]. The immunosuppressive effects arising from the hyperactivation of the kynurenine pathway might further delay the clearance of SARS-CoV-2 and cause cytokine storm and multiorgan failure. In accordance with general kynurenine pathway changes mentioned before, IDO-Kyn-AhR pathway is activated by IFN- $\beta$ or IFN- $\gamma$ in alveolar epithelial cells, leading to an accumulation of mucins, thus triggering hypoxia of COVID-19 [28].

Therefore, the hyperactivation of the kynurenine pathway provides a potent explanation of the COVID-19 pathological process, indicating a potential therapeutic approach by targeting the tryptophan pathway. Among the pharmacological agents targeting tryptophan pathways, IDO inhibitors are the most clinically advanced, which prevent immune suppression caused by tryptophan depletion and kynurenine metabolites [29,30]. However, no clinical trials have been conducted concerning IDO inhibitors in COVID-19 infection. Further research is expected to explore their effects.

\subsubsection{Arginine Reprogramming}

Arginine, a semi-essential amino acid, is primarily involved in both the generation of proteins and the production of metabolites by the catalysis of four sets of enzymes: arginine:glycine amidinotransferase, arginases, NO synthases, and arginine decarboxylase [31]. In the case of metabolic or traumatic stress, arginine is depleted, despite the fact that it can be endogenously synthesized [32]. Arginine starvation suppresses T cell activity by blocking cyclin D3 and cyclin-dependent kinase, which are fundamental in regulating T-cell-cycle progression [33]. In contrast, elevating arginine levels not only improve metabolic fitness of activated T cells, but also promote $\mathrm{T}$ cell survival through the action of three transcriptional regulators [34].

Consistent with the pattern mentioned above, COVID-19 patients present with acute arginine depletion, which is significantly associated with T cell defects [25,35]. Arginine supplements restore T cells' ability of proliferation ex vivo among COVID-19 patients [25]. These findings suggest arginine supplementation may be an adjuvant therapy, which is discussed below. 
A number of researchers have shown that arginine supplements are beneficial to a diversity of critically ill populations with clinical safety [36]. Two clinical trials concerning arginine supplements in COVID-19 are underway (NCT04404426, NCT04637906). Interestingly, as a key metabolite for viral replication, arginine depletion has also been proposed as a potential therapeutic approach for treating COVID-19 patients [37]. The balance between antiviral and immune suppression effects should be taken into consideration to confirm the optimal dosing window and proper timing of intervention for arginine-related treatment in the course of COVID-19.

\subsubsection{Glutamine Metabolism}

Glutamine, a non-essential amino acid, has diverse physiological roles, such as energy generation, lipid synthesis, purine synthesis and glutathione production [38]. Moreover, glutamine has also been revealed as a necessary nutrient for the functions of immune cells, including lymphocyte, macrophage and neutrophil, all of which are important for immune protection against viral infection [39]. Given the consumption of glutamine by human organs and immune cells increases considerably when subjected to stressful conditions, glutamine can also be condition-essential $[40,41]$.

As glutamine metabolism provides metabolic intermediates that are required for virus assembly, many viruses are likely to increase glutamine metabolism to support their replication [12]. A similar situation occurs in SARS-CoV-2 infection; COVID-19 patients have a significantly reduced glutamine to glutamate ratio, indicating increased utilization of glutamine [22]. Considering the aforementioned role of glutamine in purine synthesis and increased folate and one carbon metabolism for the synthesis of purine in SARS-CoV-2 infected cells, enhanced glutamine metabolism in COVID-19 infection may be a result of rising demand for purine synthesis, which is critical for progeny virus assembly [42]. However, inconsistent with other virus infections where glutamine replenishes the TCA cycle for the generation of energy and lipids, incorporation of glutamine into oxidized TCA cycle is reduced in SARS-CoV-2 infection, decreased expression of $\alpha$-ketoglutarate dehydrogenase complex may be a possible explanation $[38,43]$.

Synthesized from glutamate, cysteine, and glycine, glutathione (GSH) plays an important role in antioxidant defense and cell proliferation [44]. Detection of SARS-CoV-2 infected cells $8 \mathrm{~h}$ after infection showed increased GSH accompanied by a depletion in folate, raising the possibility that the antioxidant role of glutathione facilitates SARS-CoV-2 replication, protecting SARS-CoV-2 infected cells from reactive oxygen species (ROS) induced death, thus enabling the initial virus replication [42]. However, blocking glutathione synthesis did not change the progress of SARS-CoV-2 infection, suggesting increased GSH may be an epiphenomenon or can only function in a microenvironment in vivo [42]. In contrast, the detection of SARS-CoV-2 infected cells $24 \mathrm{~h}$ after infection indicated impaired biosynthesis of GSH [45]. A possible explanation is that increased methylation demands caused by SARS-CoV-2 infection give priority to utilize substrates for glutathione synthesis to generate methyl-groups [46]. Of note, decreased GSH may lead to the massive accumulation of ROS, which induce cell death and assist the release and spread of viral particles [47]. More research is needed to disclose dynamic changes in GSH and the specific functions of GSH in SARS-CoV-2 replication.

To summarize, glutamine metabolism plays a vital part in SARS-CoV-2 infection and is a potential therapeutic target in COVID-19 infection. Regarding the fact that glutamine is essential for the functions of immune cells, glutamine supplements have been proposed as an adjunctive therapy. A study including 60 COVID-19 patients, with half of the patients using L-Glutamine, showed L-Glutamine supplements in the early stage of SARS-CoV2 infection improved prognosis of COVID-19 patients [48]. Nevertheless, inhibitors of glutamine metabolism are also put forward to be beneficial in SARS-CoV-2 infection as they can deplete substrates for purine synthesis and accordingly suppress SARS-CoV2 replication. Glutamine inhibitors that target only the SARS-CoV-2 infected cells are expected to be developed to assist in the fight of COVID-19 infection (Figure 1). 


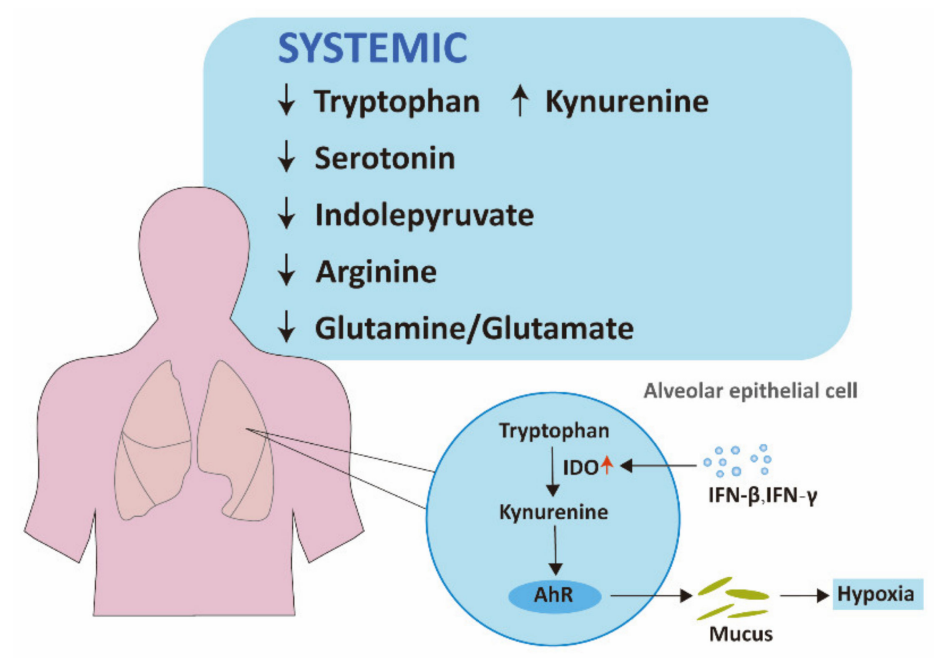

Figure 1. Altered tryptophan and arginine metabolism in COVID-19 patients. In COVID-19 infection, tryptophan metabolism is upregulated through kynurenine pathway. Mucus production is stimulated via IDO-Kyn-AhR pathway, resulting in hypoxia of COVID-19. Arginine depletion and increased glutamine metabolism is also discovered in COVID-19 patients. IFN, interferon; IDO, indoleamine2,3-dioxygenase; AhR, aryl hydrocarbon receptor.

\subsection{Glucose Metabolism and HIF}

Under normoxic, most differentiated cells metabolize glucose into pyruvate, thus feeding the mitochondrial tricarboxylic acid (TCA) cycle. Nicotinamide adenine dinucleotide $(\mathrm{NADH})$ is then produced through the TCA cycle, fueling oxidative phosphorylation (OXPHOS) for the maximum generation of ATP. It is only under hypoxia that pyruvate is directly converted into lactate[49]. Comprised of HIF-1 $\alpha$ and HIF-1 $\beta$ subunits, hypoxiainducible factor 1 (HIF-1) plays a huge part in the shift of metabolism toward anaerobic glycolysis [50]. In contrast, lactate fermentation is the chief driver of energy production in cancer cells, regardless of oxygen level. Such metabolism change is called aerobic glycolysis, or the Warburg effect $[49,51]$.

Many viruses are reported to enhance glycolysis, which allows the rapid production of energy and other substrates necessary for viral replication [3]. Consistent with such mode, metabolomic, proteomic and transcriptomic analyses have revealed increased levels of pyruvate, pyruvate kinase and lactate dehydrogenase (LDH) in COVID-19, all of which are metabolites or enzymes of glycolysis, indicating enhanced glucose metabolism for lactate fermentation [52-55]. Glycolysis is of vital importance for SARS-CoV-2 to replicate [56,57]. Increased glycolysis in monocyte not only sustains cytokine production including TNF- $\alpha$, IL-1 $\beta$, and IL-6, but also brings about T cell impairment and lung epithelial cell death [57].

HIF-1 $\alpha$ is a powerful inductor of glycolysis in COVID-19. Enzymes involved in glycolysis, including hexokinase 1 /hexokinase 3, aldolase A, pyruvate kinase 2, and lactate dehydrogenase A/lactate dehydrogenase B, were significantly upregulated by HIF1 signaling [54]. Several studies have identified the upregulation of HIF $1 \propto[55,57]$. Both hypoxia and reactive oxygen species (ROS) mediate HIF-1 $\alpha$ stabilization [57,58]. However, comprehensive mechanism accounting for increased HIF-1 $\alpha$ in COVID-19 infection remains unclear. The research focusing on AKT/mTOR/HIF-1 signaling shows reduced expression of HIF- $1 \alpha$, which is inconsistent with the studies described before [55,57]. Notwithstanding activation of Akt-mTOR pathway, HIF-1 $\alpha$ expression is suppressed in SARS-CoV-2 infected cell line Huh7 [59]. Further research is indispensable to disclose the role of Akt-mTOR signaling in the regulation of HIF-1 $\alpha$ expression in SARS-CoV-2 infection.

Besides, HIF-1 $\alpha$ plays a significant regulatory role in immune response[60]. As a transcriptional suppressor of interferon regulatory factor (IRF)5, HIF-1 $\alpha$ suppresses type I interferon, partly explaining the impaired IFN production in severe COVID-19 infections [61]. 
Given the close connection between increased glycolysis and inflammation response in COVID-19 infection, inhibiting glycolysis is emerging as an attractive therapeutic modality. Here, we discuss the potential therapeutic effects of a ketogenic diet (KD) and HIF inhibitors.

$\mathrm{KD}$, a high fat but low carbohydrate diet, is proposed to switch the metabolism from glycolysis to ketogenesis by lowering the availability of glucose [62]. Through activation of protective effect of $\gamma \delta$ T cell responses, KD restrains infection of coronavirus and influenza virus in mice $[63,64]$. Retrospective analysis has shown clinical efficacy of KD in COVID-19 cytokine storm [65]. Randomized controlled trial (NCT04492228) is in progress to confirm the preliminary data.

Concerning the crucial part of HIF-1 $\alpha$ in enhanced glycolysis and immune regulatory activities in SARS-CoV-2 infection, treatment efficacy of HIF inhibitors is worthy of examination. Plenty of clinical trials have inquired into the therapeutic implication of HIF inhibitors on cancers, providing convenience for research on HIF-1 inhibitors in COVID-19 [66] (Figure 2).

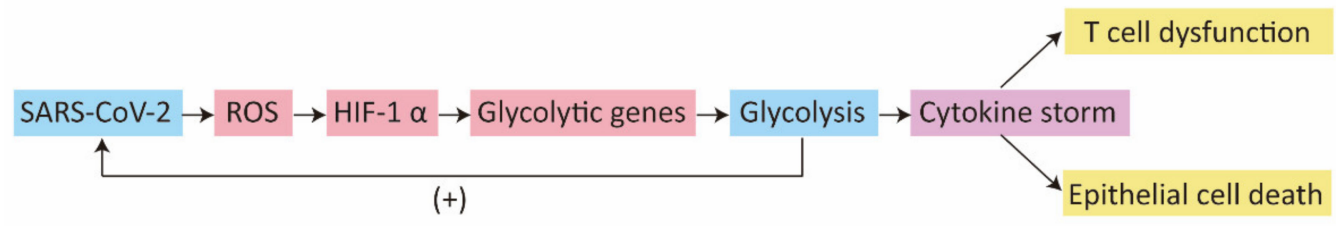

Figure 2. Schematic view of how SARS-CoV-2 enhances glycolysis and subsequent pathological change. SARS-CoV2 induces glycolysis in a ROS/HIF- $1 \alpha$ dependent way. Increased glycolysis fosters replication of SARS-CoV-2 and cytokine storm, giving rise to $\mathrm{T}$ cell impairment and lung epithelial cell death. ROS, reactive oxygen species; HIF, hypoxia-inducible factor.

\subsection{Cholesterol Metabolism}

Cholesterol is an essential lipid for appropriate cellular and systemic functions. Mainly localized to cell membranes, cholesterol not only regulates the rigidity and fluidity of the membrane, but also modulates the conformations of transmembrane proteins [67]. The homeostasis of cholesterol metabolism depends on the dynamic equilibrium between uptake, de novo biosynthesis, conversion, esterification and export [68]. Cholesterol is obtained either from exogenous uptake from the diet or endogenous synthesis [69]. In addition to its aforementioned role in cell membranes, cholesterol provides a substrate for the production of bile acids, steroid hormones and vitamin D. Oxysterols, which are formed in the first step of the conversion, have aroused great interest due to its multiple biological role [70]. Redundant cellular cholesterol is esterified to cholesteryl esters by cholesterol acyltransferase (ACAT), most of which are thus stored in cytoplasmic lipid droplets [71]. Exported to the blood, cholesteryl, esters can also serve as a chief component of plasma lipoproteins, including very-low-density lipoproteins (VLDLs), low-density lipoproteins (LDLs) and high-density lipoproteins (HDLs) [67].

Cholesterol is important for the entry and replication of SARS-CoV-2. Spike protein of SARS-CoV-2 interacts with HDL or its components, facilitating SARS-CoV-2 entry in a way dependent on ACE2 through scavenger receptor B type 1 (SR-B1) [72]. Membrane cholesterol is essential for the fusion of SARS-CoV-2 spike protein in a raft-independent way [73]. Accumulation of lipid droplets (LDs), which reserve cholesterol esters and triacylglycerols to fulfil diverse intentions, is a distinct characteristic of SARS-CoV-2 infected cells $[74,75]$. Inhibition of LD formation significantly suppresses SARS-CoV-2 replication, demonstrating the essential role of cholesterol metabolic reprogramming in SARS-CoV-2 pathogenesis [74].

Cholesterol 25-hydroxylase (CH25H) is an interferon-stimulated gene (ISG) which encodes the enzyme that produces oxysterol 25-hydroxycholesterol $(25 \mathrm{HC})$ from cholesterol [76]. The level of $\mathrm{CH} 25 \mathrm{H}$ is increased in two SARS-CoV-2 infected lung epithelial cell lines ex vivo, as well as macrophages and epithelial cells in COVID-19 patients [77]. 
Depleting membrane cholesterol by stimulating the ER-localized acyl-CoA:cholesterol acyltransferase (ACAT), 25HC suppresses membrane fusion and thus inhibits SARS-CoV-2 replication [77]. In line with these findings, another research confirms the antiviral function of $25 \mathrm{HC}$ in SARS-CoV-2 and provides the explanation of the mechanism as blockade of cholesterol export [78]. Besides, oxysterol 27-hydroxycholesterol (27HC) is also reported to pose an antiviral activity against SARS-CoV-2 [79] (Figure 3).

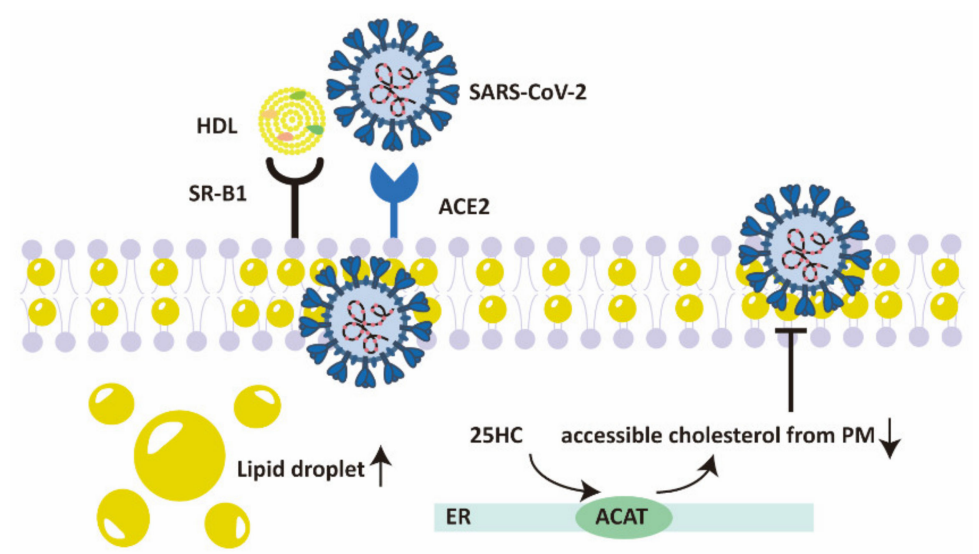

Figure 3. The role of cholesterol in regulating the entry of SARS-CoV-2. HDL-scavenger receptor B type 1 (SR-B1) facilitates SARS-CoV-2 entry in an ACE2-dependent manner. Accumulation of lipid droplets is a marked characteristic of SARS-CoV-2 infected cells. $25 \mathrm{HC}$ depletes accessible cholesterol from plasma membrane by stimulating the ER-localized ACAT, thus suppressing membrane fusion of SARS-CoV-2. HDL, high-density lipoprotein; SR-B1, scavenger receptor B type 1; ACE2, angiotensin-converting enzyme 2; 25HC, 25-hydroxycholesterol; ER, endoplasmic reticulum; ACAT, acyl-CoA:cholesterol acyltransferase.

A decrease in cholesterol level has been revealed by a quantity of researchers since the outbreak of COVID-19. The main sterol precursor of cholesterol, namely desmosterol and lathosterol, are remarkably decreased in moderate and severe COVID-19 patients [79]. Several retrospective reviews of COVID-19 patients have found a significant decrease in total cholesterol (TC), LDL-C and HDL-C [80-83], all of which are correlated with disease severity and are predictors of clinical prognosis [84-87]. Muti-omic analyses as well as clinical research has also uncovered the downregulation of multiple lipoproteins, especially apolipoproteinA-1 (APOA1) in COVID-19 patients [20,22,87-89]. Remarkably, only 27HC has been noted to decrease in COVID-19 patients among the three oxysterols, i.e., 24hydroxycholesterol (24HC), 25HC and 27HC [79]. In symptomatic COVID-19 patients, $25 \mathrm{HC}$ is even slightly increased [79]. The elevation of 25HC in a fatal COVID-19 case and hACE2 mice infected with SARS-CoV-2 is indicated in another study [90]. As $\mathrm{CH} 25 \mathrm{H}$ is an ISGs, IFN mediated production of $25 \mathrm{HC}$ may be a possible explanation for the elevation of $25 \mathrm{HC}$.

Various mechanisms are proposed to give an explanation for the decrease in cholesterol in COVID-19 patients. A basic understanding is SARS-CoV-2 consumption of cholesterol, given the vital function of cholesterol in SARS-CoV-2 entry and replication. Evidence confirming the understanding is the aforementioned fact that the decrease in cholesterol is connected with disease severity, which is usually linked to a higher virus load [91]. Another explanation is HDL-mediated depletion of cholesterol is an inflammatory state, which causes accretion of the acute phase protein serum amyloid A (SAA) within HDL and leads to increased clearance of HDL [92]. Based on these findings, HDL is speculated to consume cholesterol during COVID-19 infection [81]. Deeper investigations are imperative for the verification of the speculation. Liver damage, inflammatory cytokines, free radicals as well as alternations of vascular permeability may contribute to hypolipidemia in COVID19 [82]. Despite these hypotheses, there is a growing interest in reprogramming cholesterol metabolism in SARS-CoV-2 infected cells. 
Ordinarily, the majority of viruses tend to increase lipid synthesis to obtain enough substrates and energy for virus replication [2,4], whereas RNA sequencing analysis of human airways and alveolar organoids infected with SARS-CoV-2 showed down-regulation of several proteins related to cholesterol metabolism, including fatty acid-binding proteins (FABPs) $1 / 2 / 6, \mathrm{APOA} 1 / 4, \mathrm{APOB}, \mathrm{APOC} 4$ [93]. It is well known that sterol regulatory element binding protein-2 (SREBP-2) is activated under decreased cholesterol levels in serum to maintain cholesterol homeostasis [94]. SREBP2 is highly activated in COVID-19 patents' peripheral blood mononuclear cells (PBMCs) [95]. However, up-regulation of cholesterol synthesis-suppressing genes Sestrin-1 and PCSK9 suppress SREBP-2-induced cholesterol biosynthesis in COVID-19 patents' PBMCs [95]. More questions remain to be solved as to how cellular cholesterol metabolism changes during SARS-CoV-2 infection and in what way the decreased cholesterol level affects SARS-CoV-2 infection.

Using a genome-scale CRISPR loss-of-function screen and single-cell transcriptomics, collective transcriptional alternations in the synthesis of cholesterol next to deprivation of six genes are identified inhuman alveolar epithelial cells infected with SARS-CoV-2 [96]. CRISPR-driven deprivation of the six genes (RAB7A, PIK3C3, NPC1, CCDC22, ATP6V1A, and ATP6AP1) results in the induction of cholesterol synthesis [96]. Amlodipine, a calciumchannel antagonist that upregulates intercellular cholesterol level, leads to reduced SARSCoV-2 viral infection [96]. Induction of the cholesterol biosynthesis pathway is implied as a prospective means to restrain SARS-CoV-2 infection in another research [97].

Taken together, the adjustment of cholesterol metabolism is an appealing therapeutic method in COVID-19 infection. Statins, inhibitors of the important cholesterol synthetic enzyme HMG-CoA reductase, are a category of lipid-lowering drugs with widespread availability, low cost and great safety [98]. Besides their lipid-lowering activity, stains are known for antithrombotic, anti-inflammatory and immunomodulatory properties $[99,100]$. As a result, statin therapy is expected to be a supplementary therapy for COVID-19 [101]. A series of studies analyzed the effect of statin use on prognosis in COVID-19 infection. A large retrospective analysis on 13,981 COVID-19 patients in Hubei, China, indicated in-hospital statin use significantly decreases all-cause mortality [102]. Statin-associated improved prognosis is partially attributed to the relieved inflammatory response [102]. A number of other researchers have confirmed the beneficial role of statin-use in COVID-19 infection [103-111]. Of note, an updated meta-analysis of 22 studies suggested stains use in COVID-19 patients were connected to an approximately 35\% decrease in the adjusted risk of mortality [112]. In spite of these encouraging outcomes of statin use in COVID19 , conflicting results were reported. A meta-analysis of 9 studies which includes 3449 COVID-19 patients in total revealed no improvement of clinical outcomes after statin use [113]. Another nationwide cohort study in Denmark suggested uniformity in all-cause mortality between statin users and nonusers in COVID-19 patients [114]. In view of the lack of randomize controlled trail, statin is currently recommended only if there is an indication [115]. From the point of cholesterol reprogramming in COVID-19 infection, particular attention should be given to the potentially beneficial role of statin in depleting cholesterol needed for the entry and replication of SARS-CoV-2, as well as the prospective disadvantage of leading to low level cholesterol, which is associated with a worse clinical prognosis (Table 1). 
Table 1. Retrospective studies on COVID-19-associated hypolipidemia.

\begin{tabular}{|c|c|c|}
\hline Study Population & Lipid Changes in COVID-19 & References \\
\hline $\begin{array}{l}519 \text { severe COVID-19 patients from the West Court } \\
\text { of Union Hospital in Wuhan, China }\end{array}$ & Decrease of TC and HDL-C in non-survivors vs survivors & [80] \\
\hline $\begin{array}{l}114 \text { COVID-19 patients from Wenzhou Central } \\
\text { Hospital, in Wenzhou, China }\end{array}$ & $\begin{array}{c}\text { Decrease of TC, LDL-C and HDL-C in COVID-19 patients vs } \\
\text { healthy controls } \\
\text { Decrease of HDL-C in severe vs common groups }\end{array}$ & [81] \\
\hline $\begin{array}{l}597 \text { COVID-19 patients from the Cancer Center, } \\
\text { Union Hospital of Tongji Medical College, Wuhan }\end{array}$ & $\begin{array}{c}\text { Decrease of TC, LDL-C and HDL-C in COVID-19 patients vs } \\
\text { healthy controls } \\
\text { Decrease of TC and LDL-C in with disease severity }\end{array}$ & [82] \\
\hline $\begin{array}{l}115 \text { COVID-19 patients from Union Hospital of } \\
\text { Tongji Medical College affiliated Huazhong } \\
\text { University of Science and Technology }\end{array}$ & $\begin{array}{c}\text { Decrease of HDL-C in COVID-19 patients vs healthy } \\
\text { controls }\end{array}$ & [83] \\
\hline $\begin{array}{l}228 \text { COVID-19 patients from Public Health } \\
\text { Treatment Center of Changsha, China }\end{array}$ & $\begin{array}{c}\text { Decrease of TC, LDL-C and HDL-C in COVID-19 patients vs } \\
\text { healthy controls } \\
\text { Decrease of HDL-C in with disease severity }\end{array}$ & [84] \\
\hline $\begin{array}{l}17 \text { surviving and } 4 \text { non-surviving COVID-19 } \\
\text { patients from Zhongnan Hospital of Wuhan } \\
\text { University in Wuhan, China }\end{array}$ & $\begin{array}{c}\text { Decrease of TC, LDL-C and HDL-C in non-survivors vs } \\
\text { survivors } \\
\text { Decrease of LDL-C in with disease severity }\end{array}$ & [85] \\
\hline $\begin{array}{l}99 \text { COVID-19 patients from Leishenshan Hospital } \\
\text { in Wuhan, China. }\end{array}$ & Decrease of HDL-C in with disease severity & [87] \\
\hline
\end{tabular}

TC, total cholesterol; LDL-C, low-density lipoprotein cholesterol; HDL-C, high-density lipoprotein cholesterol.

\subsection{Fatty Acid Metabolism}

Similar to cholesterol, synthesis of fatty acids is also of critical significance for the synthesis of membranes and replication of viruses [116,117]. Two key metabolic enzymes in fatty acid biosynthesis are Acetyl-CoA carboxylase (ACC) and fatty acid synthase (FASN). ACC converts acetyl-CoA to malonyl CoA, which is then transferred to fatty acid synthesis (FAS) [118]. Using acetyl-CoA and malonyl CoA as substrates, FASN catalyzes the elongation of fatty acids [119]. Expression of ACC and FASN are regulated by SREBP1 [120]. Fatty acids are converted back into acetyl-CoA through fatty acid oxidation (FAO), which is also known as $\beta$-oxidation [121].

Activation of PI3K/AKT/mTOR/S6K signaling activity in SARS-CoV-2 infection is likely to increase ACC and FASN, thus facilitating fatty acid biosynthesis to provide enough substrates for replication [59,122]. Upregulation of SREBP1 after SARS-CoV-2 infection indicates enhanced fatty acid metabolism [74]. Transcriptome data from SARS-CoV-2 infected Calu-3 human lung epithelial cells showed hyperactivation of biological functions associated with fatty acids synthesis [123]. Increase in fatty acids abundance in COVID-19 patients have been found in a number of research; hydrolysis of phospholipids catalysed by phospholipase A2 (PLA2) is proposed as a potential explanation for increased fatty acids $[124,125]$. Remarkably, arachidonic acid and oleic acid were reliable predictors of disease severity [124]. Inhibitors of up- and downstream of FASN as well as FASN knockout resulted in suppression of SARS-CoV-2 replication, supply of fatty acid after FASN knockout rescued damaged SARS-CoV-2 replication [126]. Proteomic analysis of autopsy samples from COVID-19 patients indicated activation of FAO in most organs, implying reprogramming to a more efficient energy production mode [127]. Taken together, these findings suggest the essential part of fatty acids metabolism in SARS-CoV-2 replication, offering an appealing therapeutic target.

As common medicines with well-established safety, orlistat and metformin are proposed as potential anti-SARS-CoV-2 treatments on the basis of their respective role in inhibiting FASN and activating AMPK, which cause the decrease of fatty acid synthesis for impaired replication complex formation [122]. Randomized controlled clinical trials are required to verity their efficacy (Figure 4 ). 


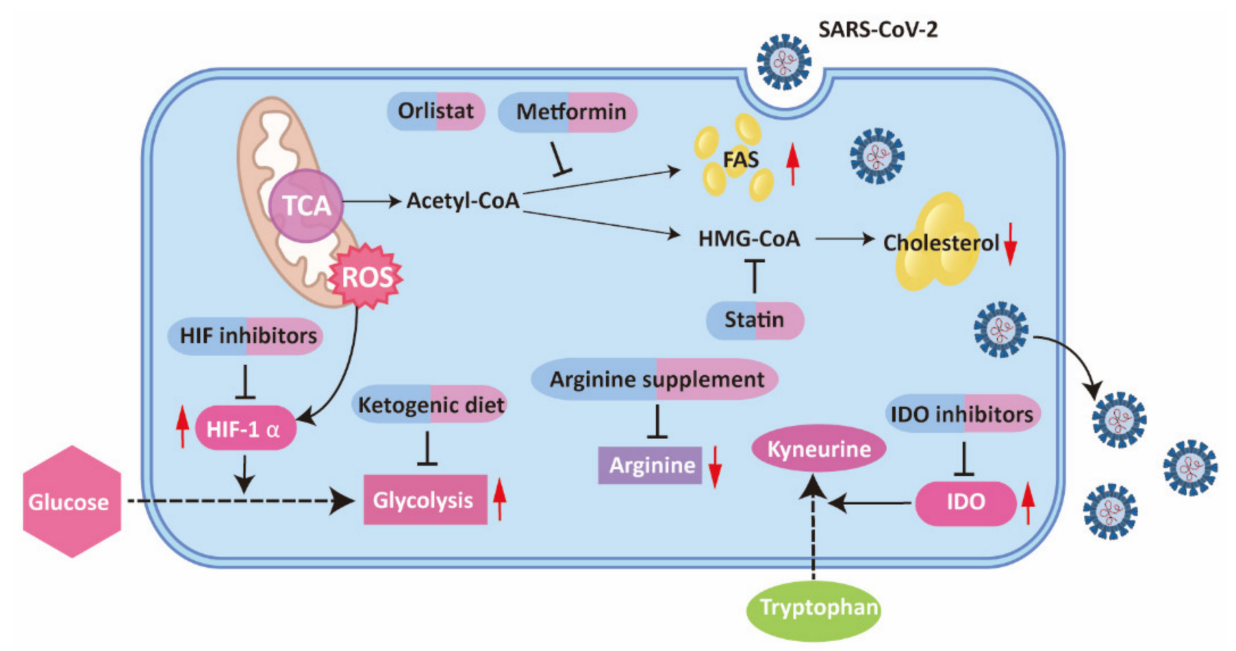

Figure 4. Metabolic reprogramming and corresponding therapeutic approaches in COVID-19. In COVID-19, tryptophan metabolism, glycolysis and fatty acid metabolism are upregulated, while cholesterol and arginine are decreased. Therapeutic agents targeting the reprogrammed metabolism in COVID-19 are shown in the figure. TCA, trichloroacetic acid; ROS, reactive oxygen species; HIF, hypoxia-inducible factor; FAS, fatty acid synthesis; HMG-CoV, 3-hydroxy-3-methylglutarylcoenzyme A; IDO, indoleamine-2,3-dioxygenase.

\section{Conclusions and Future Direction}

Metabolic reprogramming plays multiple roles in COVID-19 infection, not only offering energy and essential substrates for SARS-CoV-2 replication, but also regulating immune response. From this perspective, COVID-19 can be understood as a metabolic disease, and both pathology and therapeutics can center on reprogrammed metabolism. Such novel treatments are currently being examined and are anticipated to be powerful adjuvant therapies for COVID-19 infection.

It is worth pointing out that pre-existing metabolism derailments may fire up metabolic reprograming in COVID-19 infection due to different levels of available nutrition and influence on immune response. A typical example of the effects of different levels of nutrition is the increased mortality in COVID-19 patients with diabetes or hyperglycemia. Increased COVID-19 mortality caused by diabetes or hyperglycemia might be a result of elevated glucose levels, which provides massive substrates for enhanced glycolysis, which subsequently generates energy and components for SARS-CoV-2 replication $[57,128]$. As for the influence on immune response, patients with metabolic diseases such as diabetes and obesity often respond to infection with a proinflammatory patterns rather than a protective pattern, which may lead to increased production of cytokines and ROS in COVID-19 infection, fueling the IFN-IDO-Kyn pathway and ROS-Glycolysis axis [129]. As a result, future research targeting metabolic alternations in COVID-19 infections should pay special attention to pre-existing metabolism derailments in order to achieve a deeper understanding of metabolic reprograming in the pathophysiology of COVID-19.

Author Contributions: Both T.S. and T.W. contributed to the design, writing, and editing of manuscript. All authors have read and agreed to the published version of the manuscript.

Funding: This research was funded by grants from National Natural Science Foundation of China (82072648 and 81772542), the Fundamental Research Funds for the Central Universities (0214 14380500).

Conflicts of Interest: The authors declare no conflict of interest. 


\section{References}

1. Moreno-Altamirano, M.M.B.; Kolstoe, S.E.; Sánchez-García, F.J. Virus Control of Cell Metabolism for Replication and Evasion of Host Immune Responses. Front. Cell. Infect. Microbiol. 2019, 9, 95. [CrossRef]

2. Thaker, S.K.; Ch'ng, J.; Christofk, H.R. Viral hijacking of cellular metabolism. BMC Biol. 2019, 17, 59. [CrossRef]

3. Sanchez, E.L.; Lagunoff, M. Viral activation of cellular metabolism. Virology 2015, 479-480, 609-618. [CrossRef]

4. Goodwin, C.M.; Xu, S.; Munger, J. Stealing the Keys to the Kitchen: Viral Manipulation of the Host Cell Metabolic Network. Trends Microbiol. 2015, 23, 789-798. [CrossRef]

5. Twomey, J.D.; Luo, S.; Dean, A.Q.; Bozza, W.P.; Nalli, A.; Zhang, B. COVID-19 update: The race to therapeutic development. Drug Resist. Updates 2020, 53, 100733. [CrossRef] [PubMed]

6. Asselah, T.; Durantel, D.; Pasmant, E.; Lau, G.; Schinazi, R.F. COVID-19: Discovery, diagnostics and drug development. J. Hepatol. 2021, 74, 168-184. [CrossRef] [PubMed]

7. Zhou, Y.; Chi, J.; Lv, W.; Wang, Y. Obesity and diabetes as high-risk factors for severe coronavirus disease 2019 (Covid-19). Diabetes Metab. Res. Rev. 2021, 37, e3377. [CrossRef]

8. Drucker, D.J. Diabetes, obesity, metabolism, and SARS-CoV-2 infection: The end of the beginning. Cell Metab. 2021, 33, 479-498. [CrossRef]

9. Loftus, R.M.; Finlay, D.K. Immunometabolism: Cellular Metabolism Turns Immune Regulator. J. Biol. Chem. 2016, 291, 1-10. [CrossRef]

10. Grohmann, U.; Bronte, V. Control of immune response by amino acid metabolism. Immunol. Rev. 2010, 236, 243-264. [CrossRef]

11. Tomé, D. Amino acid metabolism and signalling pathways: Potential targets in the control of infection and immunity. Nutr. Diabetes 2021, 11, 20. [CrossRef]

12. Hirabara, S.M.; Gorjao, R.; Levada-Pires, A.C.; Masi, L.N.; Hatanaka, E.; Cury-Boaventura, M.F.; da Silva, E.B.; Santos-Oliveira, L.C.D.; Sousa Diniz, V.L.; Serdan, T.A.D.; et al. Host cell glutamine metabolism as a potential antiviral target. Clin. Sci. 2021, 135, 305-325. [CrossRef]

13. Badawy, A.A.B. Tryptophan availability for kynurenine pathway metabolism across the life span: Control mechanisms and focus on aging, exercise, diet and nutritional supplements. Neuropharmacology 2017, 112, 248-263. [CrossRef]

14. Bender, D.A. Effects of a dietary excess of leucine on the metabolism of tryptophan in the rat: A mechanism for the pellagragenic action of leucine. Br. J. Nutr. 1983, 50, 25-32. [CrossRef] [PubMed]

15. Cervenka, I.; Agudelo, L.Z.; Ruas, J.L. Kynurenines: Tryptophan's metabolites in exercise, inflammation, and mental health Science 2017, 357, eaaf9794. [CrossRef]

16. Platten, M.; Nollen, E.A.A.; Röhrig, U.F.; Fallarino, F.; Opitz, C.A. Tryptophan metabolism as a common therapeutic target in cancer, neurodegeneration and beyond. Nat. Rev. Drug Discov. 2019, 18, 379-401. [CrossRef] [PubMed]

17. Lee, G.K.; Park, H.J.; Macleod, M.; Chandler, P.; Munn, D.H.; Mellor, A.L. Tryptophan deprivation sensitizes activated T cells to apoptosis prior to cell division. Immunology 2002, 107, 452-460. [CrossRef] [PubMed]

18. Munn, D.H.; Mellor, A.L. Indoleamine 2,3 dioxygenase and metabolic control of immune responses. Trends Immunol. 2013, 34, 137-143. [CrossRef]

19. Lionetto, L.; Ulivieri, M.; Capi, M.; De Bernardini, D.; Fazio, F.; Petrucca, A.; Pomes, L.M.; De Luca, O.; Gentile, G.; Casolla, B.; et al. Increased kynurenine-to-tryptophan ratio in the serum of patients infected with SARS-CoV2: An observational cohort study. Biochim. Biophys. Acta Mol. Basis Dis. 2021, 1867, 166042. [CrossRef]

20. Shen, B.; Yi, X.; Sun, Y.; Bi, X.; Du, J.; Zhang, C.; Quan, S.; Zhang, F.; Sun, R.; Qian, L.; et al. Proteomic and Metabolomic Characterization of COVID-19 Patient Sera. Cell 2020, 182, 59-72. [CrossRef]

21. Thomas, T.; Stefanoni, D.; Reisz, J.A.; Nemkov, T.; Bertolone, L.; Francis, R.O.; Hudson, K.E.; Zimring, J.C.; Hansen, K.C.; Hod, E.A.; et al. COVID-19 infection alters kynurenine and fatty acid metabolism, correlating with IL-6 levels and renal status. JCI Insight 2020, 5. [CrossRef] [PubMed]

22. Kimhofer, T.; Lodge, S.; Whiley, L.; Gray, N.; Loo, R.L.; Lawler, N.G.; Nitschke, P.; Bong, S.-H.; Morrison, D.L.; Begum, S.; et al. Integrative Modeling of Quantitative Plasma Lipoprotein, Metabolic, and Amino Acid Data Reveals a Multiorgan Pathological Signature of SARS-CoV-2 Infection. J. Proteome Res. 2020, 19, 4442-4454. [CrossRef]

23. Xiao, N.; Nie, M.; Pang, H.; Wang, B.; Hu, J.; Meng, X.; Li, K.; Ran, X.; Long, Q.; Deng, H.; et al. Integrated cytokine and metabolite analysis reveals immunometabolic reprogramming in COVID-19 patients with therapeutic implications. Nat. Commun. 2021, 12, 1618. [CrossRef]

24. Soria-Castro, R.; Meneses-Preza, Y.G.; Rodríguez-López, G.M.; Romero-Ramírez, S.; Sosa-Hernández, V.A.; Cervantes-Díaz, R.; Pérez-Fragoso, A.; Torres-Ruíz, J.J.; Gómez-Martín, D.; Campillo-Navarro, M.; et al. Severe COVID-19 is marked by dysregulated serum levels of carboxypeptidase A3 and serotonin. J. Leukoc. Biol. 2021, 110, 425-431. [CrossRef] [PubMed]

25. Reizine, F.; Lesouhaitier, M.; Gregoire, M.; Pinceaux, K.; Gacouin, A.; Maamar, A.; Painvin, B.; Camus, C.; Le Tulzo, Y.; Tattevin, P.; et al. SARS-CoV-2-Induced ARDS Associates with MDSC Expansion, Lymphocyte Dysfunction, and Arginine Shortage. J. Clin. Immunol. 2021, 41, 515-525. [CrossRef]

26. Kim, S.; Miller, B.J.; Stefanek, M.E.; Miller, A.H. Inflammation-induced activation of the indoleamine 2,3-dioxygenase pathway: Relevance to cancer-related fatigue. Cancer 2015, 121, 2129-2136. [CrossRef] [PubMed] 
27. Takikawa, O.; Kuroiwa, T.; Yamazaki, F.; Kido, R. Mechanism of interferon-gamma action. Characterization of indoleamine 2,3-dioxygenase in cultured human cells induced by interferon-gamma and evaluation of the enzyme-mediated tryptophan degradation in its anticellular activity. J. Biol. Chem. 1988, 263, 2041-2048. [CrossRef]

28. Liu, Y.; Lv, J.; Liu, J.; Li, M.; Xie, J.; Lv, Q.; Deng, W.; Zhou, N.; Zhou, Y.; Song, J.; et al. Mucus production stimulated by IFN-AhR signaling triggers hypoxia of COVID-19. Cell Res. 2020, 30, 1078-1087. [CrossRef]

29. Lemos, H.; Huang, L.; Prendergast, G.C.; Mellor, A.L. Immune control by amino acid catabolism during tumorigenesis and therapy. Nat. Rev. Cancer 2019, 19, 162-175. [CrossRef]

30. Prendergast, G.C.; Malachowski, W.P.; DuHadaway, J.B.; Muller, A.J. Discovery of IDO1 Inhibitors: From Bench to Bedside. Cancer Res. 2017, 77, 6795-6811. [CrossRef] [PubMed]

31. Morris, S.M. Arginine Metabolism Revisited. J. Nutr. 2016, 146, 2579S-2586S. [CrossRef]

32. Patel, J.J.; Miller, K.R.; Rosenthal, C.; Rosenthal, M.D. When Is It Appropriate to Use Arginine in Critical Illness? Nutr. Clin. Pract. 2016, 31, 438-444. [CrossRef]

33. Rodriguez, P.C.; Quiceno, D.G.; Ochoa, A.C. L-arginine availability regulates T-lymphocyte cell-cycle progression. Blood 2007, 109, 1568-1573. [CrossRef] [PubMed]

34. Geiger, R.; Rieckmann, J.C.; Wolf, T.; Basso, C.; Feng, Y.; Fuhrer, T.; Kogadeeva, M.; Picotti, P.; Meissner, F.; Mann, M.; et al. L-Arginine Modulates T Cell Metabolism and Enhances Survival and Anti-tumor Activity. Cell 2016, 167, 829-842. [CrossRef]

35. Rees, C.A.; Rostad, C.A.; Mantus, G.; Anderson, E.J.; Chahroudi, A.; Jaggi, P.; Wrammert, J.; Ochoa, J.B.; Ochoa, A.; Basu, R.K.; et al. Altered amino acid profile in patients with SARS-CoV-2 infection. Proc. Natl. Acad. Sci. USA 2021, 118, e2101708118. [CrossRef]

36. Rosenthal, M.D.; Carrott, P.W.; Patel, J.; Kiraly, L.; Martindale, R.G. Parenteral or Enteral Arginine Supplementation Safety and Efficacy. J. Nutr. 2016, 146, 2594S-2600S. [CrossRef]

37. Grimes, J.M.; Khan, S.; Badeaux, M.; Rao, R.M.; Rowlinson, S.W.; Carvajal, R.D. Arginine depletion as a therapeutic approach for patients with COVID-19. Int. J. Infect. Dis. 2021, 102, 566-570. [CrossRef] [PubMed]

38. Bharadwaj, S.; Singh, M.; Kirtipal, N.; Kang, S.G. SARS-CoV-2 and Glutamine: SARS-CoV-2 Triggered Pathogenesis Metabolic Reprograming of Glutamine in Host Cells. Front. Mol. Biosci. 2020, 7, 627842. [CrossRef] [PubMed]

39. Cruzat, V.; Macedo Rogero, M.; Noel Keane, K.; Curi, R.; Newsholme, P. Glutamine: Metabolism and Immune Function, Supplementation and Clinical Translation. Nutrients 2018, 10, 1564. [CrossRef]

40. Altman, B.J.; Stine, Z.E.; Dang, C.V. From Krebs to clinic: Glutamine metabolism to cancer therapy. Nat. Rev. Cancer 2016, 16, 619-634. [CrossRef]

41. Lacey, J.M.; Wilmore, D.W. Is glutamine a conditionally essential amino acid? Nutr. Rev. 1990, 48, 297-309. [CrossRef]

42. Zhang, Y.; Guo, R.; Kim, S.H.; Shah, H.; Zhang, S.; Liang, J.H.; Fang, Y.; Gentili, M.; Leary, C.N.O.; Elledge, S.J.; et al. SARS-CoV-2 hijacks folate and one-carbon metabolism for viral replication. Nat. Commun. 2021, 12, 1676. [CrossRef]

43. Mullen, P.J.; Garcia, G.; Purkayastha, A.; Matulionis, N.; Schmid, E.W.; Momcilovic, M.; Sen, C.; Langerman, J.; Ramaiah, A.; Shackelford, D.B.; et al. SARS-CoV-2 infection rewires host cell metabolism and is potentially susceptible to mTORC1 inhibition. Nat. Commun. 2021, 12, 1876. [CrossRef] [PubMed]

44. Forman, H.J.; Zhang, H.; Rinna, A. Glutathione: Overview of its protective roles, measurement, and biosynthesis. Mol. Aspects. Med. 2009, 30, 1-12. [CrossRef]

45. Bartolini, D.; Stabile, A.M.; Bastianelli, S.; Giustarini, D.; Pierucci, S.; Busti, C.; Vacca, C.; Gidari, A.; Francisci, D.; Castronari, R.; et al. SARS-CoV2 infection impairs the metabolism and redox function of cellular glutathione. Redox Biol. 2021, $45,102041$. [CrossRef]

46. McCaddon, A.; Regland, B. COVID-19: A methyl-group assault? Med. Hypotheses 2021, 149, 110543. [CrossRef]

47. Khomich, O.A.; Kochetkov, S.N.; Bartosch, B.; Ivanov, A.V. Redox Biology of Respiratory Viral Infections. Viruses 2018, 10, 392. [CrossRef] [PubMed]

48. Cengiz, M.; Borku Uysal, B.; Ikitimur, H.; Ozcan, E.; Islamoğlu, M.S.; Aktepe, E.; Yavuzer, H.; Yavuzer, S. Effect of oral l-Glutamine supplementation on Covid-19 treatment. Clin. Nutr. Exp. 2020, 33, 24-31. [CrossRef]

49. Vander Heiden, M.G.; Cantley, L.C.; Thompson, C.B. Understanding the Warburg effect: The metabolic requirements of cell proliferation. Science 2009, 324, 1029-1033. [CrossRef] [PubMed]

50. Weidemann, A.; Johnson, R.S. Biology of HIF-1alpha. Cell. Death Differ. 2008, 15, 621-627. [CrossRef]

51. Warburg, O.; Wind, F.; Negelein, E. The metabolism of tumors in the body. J. Gen. Physiol. 1927, 8, 519-530. [CrossRef] [PubMed]

52. Jia, H.; Liu, C.; Li, D.; Huang, Q.; Liu, D.; Zhang, Y.; Ye, C.; Zhou, D.; Wang, Y.; Tan, Y.; et al. Metabolomic analyses reveals new stage-specific features of the COVID-19. Eur. Respir. J. 2021. [CrossRef]

53. Bojkova, D.; Klann, K.; Koch, B.; Widera, M.; Krause, D.; Ciesek, S.; Cinatl, J.; Münch, C. Proteomics of SARS-CoV-2-infected host cells reveals therapy targets. Nature 2020, 583, 469-472. [CrossRef] [PubMed]

54. Qi, F.; Zhang, W.; Huang, J.; Fu, L.; Zhao, J. Single-Cell RNA Sequencing Analysis of the Immunometabolic Rewiring and Immunopathogenesis of Coronavirus Disease 2019. Front. Immunol. 2021, 12, 651656. [CrossRef]

55. Zhang, Y.; Wang, S.; Xia, H.; Guo, J.; He, K.; Huang, C.; Luo, R.; Chen, Y.; Xu, K.; Gao, H.; et al. Identification of Monocytes Associated with Severe COVID-19 in the PBMCs of Severely Infected patients Through Single-Cell Transcriptome Sequencing Engineering 2021. [CrossRef] 
56. Ajaz, S.; McPhail, M.J.; Singh, K.K.; Mujib, S.; Trovato, F.M.; Napoli, S.; Agarwal, K. Mitochondrial metabolic manipulation by SARS-CoV-2 in peripheral blood mononuclear cells of patients with COVID-19. Am. J. Physiol. Cell Physiol. 2021, 320, C57-C65. [CrossRef]

57. Codo, A.C.; Davanzo, G.G.; Monteiro, L.d.B.; de Souza, G.F.; Muraro, S.P.; Virgilio-da-Silva, J.V.; Prodonoff, J.S.; Carregari, V.C.; de Biagi Junior, C.A.O.; Crunfli, F.; et al. Elevated Glucose Levels Favor SARS-CoV-2 Infection and Monocyte Response through a HIF-1 $\alpha /$ Glycolysis-Dependent Axis. Cell Metab. 2020, 32, 437-446. [CrossRef]

58. Semenza, G.L. Targeting HIF-1 for cancer therapy. Nat. Rev. Cancer 2003, 3, 721-732. [CrossRef]

59. Appelberg, S.; Gupta, S.; Svensson Akusjärvi, S.; Ambikan, A.T.; Mikaeloff, F.; Saccon, E.; Végvári, Á.; Benfeitas, R.; Sperk, M.; Ståhlberg, M.; et al. Dysregulation in Akt/mTOR/HIF-1 signaling identified by proteo-transcriptomics of SARS-CoV-2 infected cells. Emerg. Microbes Infect. 2020, 9, 1748-1760. [CrossRef] [PubMed]

60. Palazon, A.; Goldrath, A.W.; Nizet, V.; Johnson, R.S. HIF transcription factors, inflammation, and immunity. Immunity 2014, 41, 518-528. [CrossRef]

61. Peng, T.; Du, S.-Y.; Son, M.; Diamond, B. HIF-1 $\alpha$ is a negative regulator of interferon regulatory factors: Implications for interferon production by hypoxic monocytes. Proc. Natl. Acad. Sci. USA 2021, 118, e2106017118. [CrossRef] [PubMed]

62. Weber, D.D.; Aminzadeh-Gohari, S.; Tulipan, J.; Catalano, L.; Feichtinger, R.G.; Kofler, B. Ketogenic diet in the treatment of cancer-Where do we stand? Mol. Metab. 2020, 33, 102-121. [CrossRef] [PubMed]

63. Ryu, S.; Shchukina, I.; Youm, Y.-H.; Qing, H.; Hilliard, B.; Dlugos, T.; Zhang, X.; Yasumoto, Y.; Booth, C.J.; Fernández-Hernando, C.; et al. Ketogenic diet restrains aging-induced exacerbation of coronavirus infection in mice. Elife 2021, 10, e66522. [CrossRef]

64. Goldberg, E.L.; Molony, R.D.; Kudo, E.; Sidorov, S.; Kong, Y.; Dixit, V.D.; Iwasaki, A. Ketogenic diet activates protective $\gamma \delta \mathrm{T}$ cell responses against influenza virus infection. Sci. Immunol. 2019, 4, eaav2026. [CrossRef]

65. Sukkar, S.G.; Cogorno, L.; Pisciotta, L.; Pasta, A.; Vena, A.; Gradaschi, R.; Dentone, C.; Guiddo, E.; Martino, E.; Beltramini, S.; et al. Clinical efficacy of eucaloric ketogenic nutrition in the COVID-19 cytokine storm: A retrospective analysis of mortality and intensive care unit admission. Nutrition 2021, 89, 111236. [CrossRef]

66. Fallah, J.; Rini, B.I. HIF Inhibitors: Status of Current Clinical Development. Curr. Oncol. Rep. 2019, 21, 6. [CrossRef]

67. Luo, J.; Yang, H.; Song, B.-L. Mechanisms and regulation of cholesterol homeostasis. Nat. Rev. Mol. Cell Biol. 2020, 21, 225-245. [CrossRef] [PubMed]

68. Xu, H.; Zhou, S.; Tang, Q.; Xia, H.; Bi, F. Cholesterol metabolism: New functions and therapeutic approaches in cancer. Biochim. Biophys. Acta (BBA) Rev. Cancer 2020, 1874, 188394. [CrossRef]

69. Kapourchali, F.R.; Surendiran, G.; Goulet, A.; Moghadasian, M.H. The Role of Dietary Cholesterol in Lipoprotein Metabolism and Related Metabolic Abnormalities: A Mini-review. Crit. Rev. Food Sci. Nutr. 2016, 56, 2408-2415. [CrossRef]

70. Wang, Y.; Yutuc, E.; Griffiths, W.J. Cholesterol metabolism pathways-are the intermediates more important than the products? FEBS J. 2021, 288, 3727-3745. [CrossRef]

71. Chang, T.-Y.; Li, B.-L.; Chang, C.C.Y.; Urano, Y. Acyl-coenzyme A:cholesterol acyltransferases. Am. J. Physiol. Endocrinol. Metab. 2009, 297, E1-E9. [CrossRef]

72. Wei, C.; Wan, L.; Yan, Q.; Wang, X.; Zhang, J.; Yang, X.; Zhang, Y.; Fan, C.; Li, D.; Deng, Y.; et al. HDL-scavenger receptor B type 1 facilitates SARS-CoV-2 entry. Nat. Metab. 2020, 2, 1391-1400. [CrossRef] [PubMed]

73. Sanders, D.W.; Jumper, C.C.; Ackerman, P.J.; Bracha, D.; Donlic, A.; Kim, H.; Kenney, D.; Castello-Serrano, I.; Suzuki, S.; Tamura, T.; et al. SARS-CoV-2 requires cholesterol for viral entry and pathological syncytia formation. Elife 2021, 10, e65962. [CrossRef] [PubMed]

74. Dias, S.S.G.; Soares, V.C.; Ferreira, A.C.; Sacramento, C.Q.; Fintelman-Rodrigues, N.; Temerozo, J.R.; Teixeira, L.; Nunes da Silva, M.A.; Barreto, E.; Mattos, M.; et al. Lipid droplets fuel SARS-CoV-2 replication and production of inflammatory mediators. PLoS Pathog. 2020, 16, e1009127. [CrossRef]

75. Nardacci, R.; Colavita, F.; Castilletti, C.; Lapa, D.; Matusali, G.; Meschi, S.; Del Nonno, F.; Colombo, D.; Capobianchi, M.R.; Zumla, A.; et al. Evidences for lipid involvement in SARS-CoV-2 cytopathogenesis. Cell Death Dis. 2021, 12, 263. [CrossRef]

76. Liu, S.-Y.; Aliyari, R.; Chikere, K.; Li, G.; Marsden, M.D.; Smith, J.K.; Pernet, O.; Guo, H.; Nusbaum, R.; Zack, J.A.; et al. Interferon-inducible cholesterol-25-hydroxylase broadly inhibits viral entry by production of 25-hydroxycholesterol. Immunity 2013, 38. [CrossRef]

77. Wang, S.; Li, W.; Hui, H.; Tiwari, S.K.; Zhang, Q.; Croker, B.A.; Rawlings, S.; Smith, D.; Carlin, A.F.; Rana, T.M. Cholesterol 25-Hydroxylase inhibits SARS-CoV-2 and other coronaviruses by depleting membrane cholesterol. EMBO J. 2020, 39 , e106057. [CrossRef]

78. Zang, R.; Case, J.B.; Yutuc, E.; Ma, X.; Shen, S.; Gomez Castro, M.F.; Liu, Z.; Zeng, Q.; Zhao, H.; Son, J.; et al. Cholesterol 25hydroxylase suppresses SARS-CoV-2 replication by blocking membrane fusion. Proc. Natl. Acad. Sci. USA 2020, 117, 32105-32113. [CrossRef]

79. Marcello, A.; Civra, A.; Milan Bonotto, R.; Nascimento Alves, L.; Rajasekharan, S.; Giacobone, C.; Caccia, C.; Cavalli, R.; Adami, M.; Brambilla, P.; et al. The cholesterol metabolite 27-hydroxycholesterol inhibits SARS-CoV-2 and is markedly decreased in COVID-19 patients. Redox Biol. 2020, 36, 101682. [CrossRef]

80. Li, Y.; Zhang, Y.; Lu, R.; Dai, M.; Shen, M.; Zhang, J.; Cui, Y.; Liu, B.; Lin, F.; Chen, L.; et al. Lipid metabolism changes in patients with severe COVID-19. Clin. Chim. Acta 2021, 517, 66-73. [CrossRef] [PubMed] 
81. Hu, X.; Chen, D.; Wu, L.; He, G.; Ye, W. Declined serum high density lipoprotein cholesterol is associated with the severity of COVID-19 infection. Clin. Chim. Acta 2020, 510, 105-110. [CrossRef]

82. Wei, X.; Zeng, W.; Su, J.; Wan, H.; Yu, X.; Cao, X.; Tan, W.; Wang, H. Hypolipidemia is associated with the severity of COVID-19. J. Clin. Lipidol. 2020, 14, 297-304. [CrossRef] [PubMed]

83. Ding, X.; Zhang, J.; Liu, L.; Yuan, X.; Zang, X.; Lu, F.; He, P.; Wang, Q.; Zhang, X.; Xu, Y.; et al. High-density lipoprotein cholesterol as a factor affecting virus clearance in covid-19 patients. Respir. Med. 2020, 175, 106218. [CrossRef] [PubMed]

84. Wang, G.; Zhang, Q.; Zhao, X.; Dong, H.; Wu, C.; Wu, F.; Yu, B.; Lv, J.; Zhang, S.; Wu, G.; et al. Low high-density lipoprotein level is correlated with the severity of COVID-19 patients: An observational study. Lipids Health Dis. 2020, 19, 204. [CrossRef]

85. Fan, J.; Wang, H.; Ye, G.; Cao, X.; Xu, X.; Tan, W.; Zhang, Y. Letter to the Editor: Low-density lipoprotein is a potential predictor of poor prognosis in patients with coronavirus disease 2019. Metabolism 2020, 107, 154243. [CrossRef]

86. Masana, L.; Correig, E.; Ibarretxe, D.; Anoro, E.; Arroyo, J.A.; Jericó, C.; Guerrero, C.; Miret, M.1.; Näf, S.; Pardo, A.; et al. Low HDL and high triglycerides predict COVID-19 severity. Sci. Rep. 2021, 11, 7217. [CrossRef]

87. Sun, J.T.; Chen, Z.; Nie, P.; Ge, H.; Shen, L.; Yang, F.; Qu, X.L.; Ying, X.Y.; Zhou, Y.; Wang, W.; et al. Lipid Profile Features and Their Associations With Disease Severity and Mortality in Patients With COVID-19. Front. Cardiovasc. Med. 2020, 7, 584987. [CrossRef]

88. Overmyer, K.A.; Shishkova, E.; Miller, I.J.; Balnis, J.; Bernstein, M.N.; Peters-Clarke, T.M.; Meyer, J.G.; Quan, Q.; Muehlbauer, L.K.; Trujillo, E.A.; et al. Large-Scale Multi-omic Analysis of COVID-19 Severity. Cell Syst. 2021, 12, 23-40. [CrossRef] [PubMed]

89. Hilser, J.R.; Han, Y.; Biswas, S.; Gukasyan, J.; Cai, Z.; Zhu, R.; Tang, W.H.W.; Deb, A.; Lusis, A.J.; Hartiala, J.A.; et al. Association of serum HDL-cholesterol and apolipoprotein A1 levels with risk of severe SARS-CoV-2 infection. J. Lipid Res. 2021, 62, 100061. [CrossRef]

90. Zu, S.; Deng, Y.-Q.; Zhou, C.; Li, J.; Li, L.; Chen, Q.; Li, X.-F.; Zhao, H.; Gold, S.; He, J.; et al. 25-Hydroxycholesterol is a potent SARS-CoV-2 inhibitor. Cell Res. 2020, 30, 1043-1045. [CrossRef]

91. Turgay Yıldırım, Ö.; Kaya, S.. The atherogenic index of plasma as a predictor of mortality in patients with COVID-19. Heart Lung 2021, 50, 329-333. [CrossRef]

92. Feingold, K.R.; Grunfeld, C. Effect of inflammation on HDL structure and function. Curr. Opin. Lipidol. 2016, 27, 521-530. [CrossRef] [PubMed]

93. Pei, R.; Feng, J.; Zhang, Y.; Sun, H.; Li, L.; Yang, X.; He, J.; Xiao, S.; Xiong, J.; Lin, Y.; et al. Host metabolism dysregulation and cell tropism identification in human airway and alveolar organoids upon SARS-CoV-2 infection. Protein Cell 2020, 12, 717-733. [CrossRef]

94. Brown, M.S.; Goldstein, J.L. The SREBP Pathway: Regulation of Cholesterol Metabolism by Proteolysis of a Membrane-Bound Transcription Factor. Cell 1997, 89, 331-340. [CrossRef]

95. Lee, W.; Ahn, J.H.; Park, H.H.; Kim, H.N.; Kim, H.; Yoo, Y.; Shin, H.; Hong, K.S.; Jang, J.G.; Park, C.G.; et al. COVID-19-activated SREBP2 disturbs cholesterol biosynthesis and leads to cytokine storm. Signal Trans. Target. Ther. 2020, 5, 186. [CrossRef]

96. Daniloski, Z.; Jordan, T.X.; Wessels, H.-H.; Hoagland, D.A.; Kasela, S.; Legut, M.; Maniatis, S.; Mimitou, E.P.; Lu, L.; Geller, E.; et al. Identification of Required Host Factors for SARS-CoV-2 Infection in Human Cells. Cell 2021, 184, 92-105. [CrossRef] [PubMed]

97. Hoagland, D.A.; Clarke, D.J.B.; Møller, R.; Han, Y.; Yang, L.; Wojciechowicz, M.L.; Lachmann, A.; Oguntuyo, K.Y.; Stevens, C.; Lee, B.; et al. Modulating the transcriptional landscape of SARS-CoV-2 as an effective method for developing antiviral compounds. bioRxiv 2020. [CrossRef]

98. Fajgenbaum, D.C.; Rader, D.J. Teaching Old Drugs New Tricks: Statins for COVID-19? Cell Metab. 2020, 32, 145-147. [CrossRef] [PubMed]

99. Bifulco, M.; Gazzerro, P. Statin therapy in COVID-19 infection: Much more than a single pathway. Eur. Heart J. Cardiovasc. Pharmacother. 2020, 6, 410-411. [CrossRef]

100. Castiglione, V.; Chiriacò, M.; Emdin, M.; Taddei, S.; Vergaro, G. Statin therapy in COVID-19 infection. Eur. Heart J. Cardiovasc. Pharmacother. 2020, 6, 258-259. [CrossRef]

101. Ganjali, S.; Bianconi, V.; Penson, P.E.; Pirro, M.; Banach, M.; Watts, G.F.; Sahebkar, A. Commentary: Statins, COVID-19, and coronary artery disease: Killing two birds with one stone. Metabolism 2020, 113, 154375. [CrossRef] [PubMed]

102. Zhang, X.-J.; Qin, J.-J.; Cheng, X.; Shen, L.; Zhao, Y.-C.; Yuan, Y.; Lei, F.; Chen, M.-M.; Yang, H.; Bai, L.; et al. In-Hospital Use of Statins Is Associated with a Reduced Risk of Mortality among Individuals with COVID-19. Cell Metab. 2020, 32, 176-187. [CrossRef] [PubMed]

103. Yetmar, Z.A.; Chesdachai, S.; Kashour, T.; Riaz, M.; Gerberi, D.J.; Badley, A.D.; Berbari, E.F.; Tleyjeh, I.M. Prior Statin Use and Risk of Mortality and Severe Disease From Coronavirus Disease 2019: A Systematic Review and Meta-analysis. Open Forum Infect. Dis. 2021, 8, ofab284. [CrossRef]

104. Bifulco, M.; Ciccarelli, M.; Bruzzese, D.; Dipasquale, A.; Lania, A.G.; Mazziotti, G.; Gazzerro, P. The benefit of statins in SARS-CoV-2 patients: Further metabolic and prospective clinical studies are needed. Endocrine 2021, 71, 270-272. [CrossRef] [PubMed]

105. Vahedian-Azimi, A.; Mohammadi, S.M.; Heidari Beni, F.; Banach, M.; Guest, P.C.; Jamialahmadi, T.; Sahebkar, A. Improved COVID-19 ICU admission and mortality outcomes following treatment with statins: A systematic review and meta-analysis. Arch. Med. Sci. 2021, 17, 579-595. [CrossRef] [PubMed] 
106. Lee, H.-Y.; Ahn, J.; Park, J.; Kyung Kang, C.; Won, S.-H.; Wook Kim, D.; Park, J.-H.; Chung, K.-H.; Joh, J.-S.; Bang, J.H.; et al. Beneficial Effect of Statins in COVID-19-Related Outcomes-Brief Report: A National Population-Based Cohort Study. Arterioscler. Thromb. Vasc. Biol. 2021, 41, e175-e182. [CrossRef]

107. Gupta, A.; Madhavan, M.V.; Poterucha, T.J.; DeFilippis, E.M.; Hennessey, J.A.; Redfors, B.; Eckhardt, C.; Bikdeli, B.; Platt, J.; Nalbandian, A.; et al. Association between antecedent statin use and decreased mortality in hospitalized patients with COVID-19. Nat. Commun. 2021, 12, 1325. [CrossRef]

108. Lohia, P.; Kapur, S.; Benjaram, S.; Mir, T. Association between antecedent statin use and severe disease outcomes in COVID-19: A retrospective study with propensity score matching. J. Clin. Lipidol. 2021, 15, 451-459. [CrossRef] [PubMed]

109. Wu, C.-C.; Lee, A.-J.; Su, C.-H.; Huang, C.-Y.; Islam, M.M.; Weng, Y.-C. Statin Use Is Associated with a Decreased Risk of Mortality among Patients with COVID-19. J. Clin. Med. 2021, 10, 1450. [CrossRef]

110. Song, S.L.; Hays, S.B.; Panton, C.E.; Mylona, E.K.; Kalligeros, M.; Shehadeh, F.; Mylonakis, E. Statin Use Is Associated with Decreased Risk of Invasive Mechanical Ventilation in COVID-19 Patients: A Preliminary Study. Pathogens 2020, 9, 759. [CrossRef]

111. Masana, L.; Correig, E.; Rodríguez-Borjabad, C.; Anoro, E.; Arroyo, J.A.; Jericó, C.; Pedragosa, A.; Miret, M.l.; Näf, S.; Pardo, A.; et al. Effect of statin therapy on SARS-CoV-2 infection-related. Eur. Heart J. Cardiovasc. Pharmacother. 2020. [CrossRef]

112. Kollias, A.; Kyriakoulis, K.G.; Kyriakoulis, I.G.; Nitsotolis, T.; Poulakou, G.; Stergiou, G.S.; Syrigos, K. Statin use and mortality in COVID-19 patients: Updated systematic review and meta-analysis. Atherosclerosis 2021, 330, 114-121. [CrossRef]

113. Hariyanto, T.I.; Kurniawan, A. Statin therapy did not improve the in-hospital outcome of coronavirus disease 2019 (COVID-19) infection. Diabetes Metab. Syndr. 2020, 14, 1613-1615. [CrossRef]

114. Butt, J.H.; Gerds, T.A.; Schou, M.; Kragholm, K.; Phelps, M.; Havers-Borgersen, E.; Yafasova, A.; Gislason, G.H.; Torp-Pedersen, C.; Køber, L.; et al. Association between statin use and outcomes in patients with coronavirus disease 2019 (COVID-19): A nationwide cohort study. BMJ Open 2020, 10, e044421. [CrossRef]

115. Rubin, R. Could Statins Do More Than Lower Cholesterol in Patients With COVID-19? JAMA 2021, 325, 2424-2425. [CrossRef] [PubMed]

116. Sanchez, E.L.; Pulliam, T.H.; Dimaio, T.A.; Thalhofer, A.B.; Delgado, T.; Lagunoff, M. Glycolysis, Glutaminolysis, and Fatty Acid Synthesis Are Required for Distinct Stages of Kaposi's Sarcoma-Associated Herpesvirus Lytic Replication. J. Virol. 2017, 91, e02237-16. [CrossRef] [PubMed]

117. Carracedo, A.; Cantley, L.C.; Pandolfi, P.P. Cancer metabolism: Fatty acid oxidation in the limelight. Nat. Rev. Cancer 2013, 13, 227-232. [CrossRef]

118. Tong, L. Structure and function of biotin-dependent carboxylases. Cell. Mol. Life Sci. 2013, 70, 863-891. [CrossRef] [PubMed]

119. Jones, S.F.; Infante, J.R. Molecular Pathways: Fatty Acid Synthase. Clin. Cancer Res. 2015, 21, 5434-5438. [CrossRef]

120. Eberlé, D.; Hegarty, B.; Bossard, P.; Ferré, P.; Foufelle, F. SREBP transcription factors: Master regulators of lipid homeostasis. Biochimie 2004, 86, 839-848. [CrossRef]

121. Rinaldo, P.; Matern, D.; Bennett, M.J. Fatty acid oxidation disorders. Annu. Rev. Physiol. 2002, 64, 477-502. [CrossRef] [PubMed]

122. Tanner, J.E.; Alfieri, C. The Fatty Acid Lipid Metabolism Nexus in COVID-19. Viruses 2021, 13, 90. [CrossRef]

123. Shaath, H.; Alajez, N.M. Computational and Transcriptome Analyses Revealed Preferential Induction of Chemotaxis and Lipid Synthesis by SARS-CoV-2. Biology 2020, 9, 260. [CrossRef]

124. Barberis, E.; Timo, S.; Amede, E.; Vanella, V.V.; Puricelli, C.; Cappellano, G.; Raineri, D.; Cittone, M.G.; Rizzi, E.; Pedrinelli, A.R.; et al. Large-Scale Plasma Analysis Revealed New Mechanisms and Molecules Associated with the Host Response to SARS-CoV-2. Int. J. Mol. Sci. 2020, 21, 8623. [CrossRef] [PubMed]

125. Song, J.-W.; Lam, S.M.; Fan, X.; Cao, W.-J.; Wang, S.-Y.; Tian, H.; Chua, G.H.; Zhang, C.; Meng, F.-P.; Xu, Z.; et al. Omics-Driven Systems Interrogation of Metabolic Dysregulation in COVID-19 Pathogenesis. Cell Metab. 2020, 32, 188-202. [CrossRef]

126. Williams, C.G.; Jureka, A.S.; Silvas, J.A.; Nicolini, A.M.; Chvatal, S.A.; Carlson-Stevermer, J.; Oki, J.; Holden, K.; Basler, C.F. Inhibitors of VPS34 and fatty-acid metabolism suppress SARS-CoV-2 replication. Cell Rep. 2021, 36, 109479. [CrossRef] [PubMed]

127. Nie, X.; Qian, L.; Sun, R.; Huang, B.; Dong, X.; Xiao, Q.; Zhang, Q.; Lu, T.; Yue, L.; Chen, S.; et al. Multi-organ proteomic landscape of COVID-19 autopsies. Cell 2021, 184, 775-791.e14. [CrossRef] [PubMed]

128. Lim, S.; Bae, J.H.; Kwon, H.-S.; Nauck, M.A. COVID-19 and diabetes mellitus: From pathophysiology to clinical management. Nat. Rev. Endocrinol. 2021, 17, 11-30. [CrossRef] [PubMed]

129. Berber, E.; Sumbria, D.; Rouse, B.T. Could targeting immunometabolism be a way to control the burden of COVID-19 infection? Microbes Infect. 2021, 23, 104780. [CrossRef] 